\title{
Dibromohydantoins as halogen bond (XB) donors: a route toward the introduction of chirality in halogen bonded systems $\dagger$
}

Irène Nicolas, ${ }^{a}$ Olivier Jeannin, ${ }^{a}$ Delphine Pichon, ${ }^{a}$ and Marc Fourmigué ${ }^{\star a}$

\begin{abstract}
$\mathrm{N}, \mathrm{N}$-dibromohydantoins, known as electrophilic bromination reagents, are successfully used here as halogen bond (XB) donors, as demonstrated in their crystalline adducts with para-substituted pyridines acting as halogen bond acceptors. $1: 1$ adducts of the achiral 5,5-dimethyl-N,N'-dibromohydantoin (DBH) are crystallized with methylisonicotinate, 4-trifluoromethylpyridine and 4-cyanopyridine while both nitrogen atoms of pyrazine are engaged in halogen bonding in the 2:1 adduct $(\mathrm{DBH})_{2} \cdot($ pyrazine). A strengthening of the $\mathrm{XB}$ interaction between the imidic $\mathrm{N}-\mathrm{Br}$ group of $\mathrm{DBH}$ and the pyridinic nitrogen atom is observed with the more electron rich pyridines with the order: $\mathrm{Py}-\mathrm{CO}_{2} \mathrm{Me}>\mathrm{Py}_{-}-\mathrm{CF}_{3}>\mathrm{Py}-\mathrm{CN}>$ pyrazine. Chiral hydantoins and their N,N'-dibromo derivatives are obtained in good yields from different amino acids (phenylglycine, phenylalanine, valine and leucine). The ability of such enantiopure $\mathrm{N}$-iodoimides derivatives to act as halogen-bond donors is demonstrated in the 1:1 methylisonicotinate adduct with (S)-5-isobutyl-N,N'dibromohydantoin.
\end{abstract}

a Institut des Sciences Chimiques de Rennes, Université de Rennes 1, CNRS, Campus de Beaulieu, 35042 Rennes, France

$\dagger$ Electronic supplementary information (ESI) available: CCDC 1509929-1509933. For crystallographic data in CIF format see DOI: 10.1039/c6ce02175a. 


\section{Introduction}

The formation of chiral supramolecular assemblies is an attractive challenge in the context of crystal engineering, ${ }^{1,2}$ It most often relies on the use of different intermolecular interactions such as metal coordination, hydrogen bonding ${ }^{3}$ or $\pi-\pi$ interactions. ${ }^{4}$ By comparison, the use of halogen bonding ${ }^{5}(\mathrm{XB})$ as a crystal engineering tool in the formation of chiral, eventually helical structures has been only rarely mentioned, albeit XB has been also recently established as a powerful intermolecular interaction for the elaboration of complex supramolecular architectures. $^{6,7,8,9}$ One of the earliest examples is the resolution of racemic 1,2dibromohexafluoropropane through co-crystallisation with (-)-sparteine hydrobromide into supramolecular helices stabilised by $\mathrm{C}-\mathrm{Br}^{\bullet} \bullet \mathrm{Br}^{-} \mathrm{XB}$ interactions. ${ }^{10}$ Halogen bonds can be also associated with hydrogen bonding, for example in chiral amines, ${ }^{3 \mathrm{~b}}$ ammoniums salts $^{11}$ or sulfinamides. $^{12}$ Chirality has been introduced in conducting halogen bonded tetrathiafulvalenium salts, through chiral counter ions ${ }^{13}$ or chiral iodinated TTF themselves. ${ }^{14}$ One can also mention chiral nematic phases from halogen-bonded, bent-core achiral mesogen, ${ }^{15}$ host-guest compounds involving octafluorodiiodobutane, ${ }^{16}$ asymmetrical porphyrin derivatives, ${ }^{17}$ or chiral anion recognition. ${ }^{18}$ In order to favour the formation of intrinsically chiral structures based on halogen bond interactions, we are currently investigating neutral iodinated spacers with a built-in chirality and recently described ditopic halogen bond donors derived from chiral diols (Scheme 1a). ${ }^{19}$ Their crystallisation with halide anions as halogen bond acceptors afforded helical halogen bonded anionic chains. Looking for more compact but still chiral ditopic halogen bond donors, we turned our attention to $\mathrm{N}$-iodoimides derivatives, known to act powerful halogen bond donors. ${ }^{20}$ For example, $\mathrm{N}$-iodosuccinimide, ${ }^{21,22}$ or $\mathrm{N}$-iodosaccharin, ${ }^{23}$ originally used as electrophilic iodinating agents can be efficiently engaged in XB systems, for example with pyridines of various Lewis base character. ${ }^{24}$ In the same vein, N,N'-diodo-dimethylhydantoin (DIH) has found many uses in organic synthesis as halogenating agents ${ }^{25}$ or as catalysts. ${ }^{26}$ It can also act as a powerful halogen bond donor with both an imidic and an amidic N-I halogen bond donor groups (Scheme 1b). We have recently demonstrated, in the halogen bonded adducts of DIH with pyridines, an anti-cooperativity property: while the most basic pyridines were able to cocrystallize with DIH into bis-adducts where both iodine atoms are indeed involved in XB interactions, the less basic ones led to monoadducts involving only the imidic N-I moiety. ${ }^{27}$ 
(a)

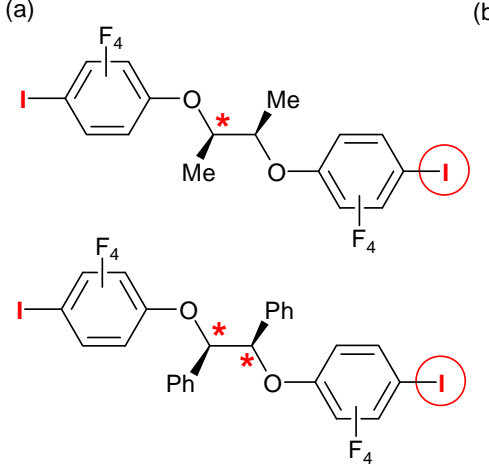

(b)
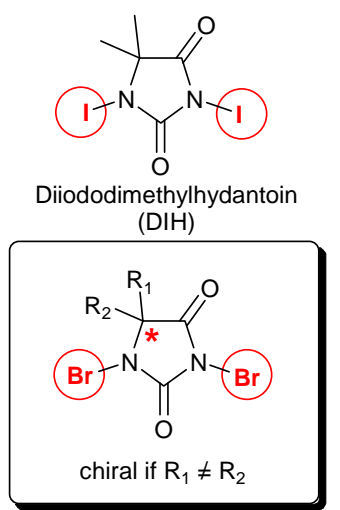

Scheme 1 (a) Chiral ditopic XB donors reported from chiral diols. ${ }^{19}$ (b) Diodo- and dibromohydantoins.

The hydantoin core offers another attractive feature associated with the substitution pattern at 5-position. Two methyl groups are found in the prototypical dimethylhydantoin and its diiodo derivative diiododimethylhydantoin $(\mathrm{DIH})$ but the presence of two different substituents at the 5-position affords indeed a chiral hydantoin (Scheme 1b). Many of them have been in fact reported in the literature for therapeutic applications, ${ }^{28}$ most of them derived from natural amino acids. On the other hand, the corresponding N,N'-dihalo derivatives of such chiral hydantoins were only scarcely mentioned. Chiral dichloro hydantoins are mentioned as a chlorenium source in asymmetric chlorolactonization reactions, ${ }^{29}$ while dibromo derivatives were only mentioned as racemic mixtures as $\mathrm{CCl}_{4}$-soluble halogenating agents. ${ }^{30}$ Chiral N,N'-diiodo derivatives are still unknown. In the following, we have explored the preparation of four different chiral N,N'-dibromohydantoin derivatives (1-R in Scheme 2) and their association, together with that of achiral 5,5-dimethyl-N,N'-dibromo derivative DBH, with pyridines of various Lewis base character. We were able to isolate single crystalline phases from the association of DBH with electron-poor pyridines such as 4cyanopyridine, 4-trifluoromethylpyridine and methylisonicotinate. Among the chiral dibromohydantoins prepared here, the 1-iBu dibromohydantoin derived from leucine was also successfully co-crystallized, in a 1:1 stoichiometry, with methylisonicotinate.

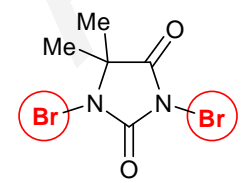

DBH

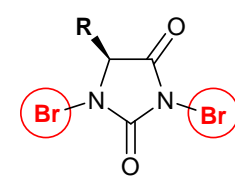

$\mathrm{R}=\mathrm{Bz} \quad 1-\mathrm{Bz}$

$\mathrm{R}=\mathrm{iPr} \quad 1-\mathrm{iPr}$

$\mathrm{R}=\mathrm{iBu} \quad$ 1-iBu

Scheme 2 Dibromohydantoins investigated with pyridines as XB acceptors. 


\section{Results and discussion}

\section{Syntheses}

The main synthetic route toward chiral hydantoins is based on the formation of an urea $2-\mathrm{R}$ from the starting amino acid methyl ester (Scheme 3). Further cyclization to the desired hydantoins 3-R can been then performed, either under acidic ${ }^{31}$ or basic conditions. ${ }^{32}$ This second step is often difficult because affected by racemisation problems. As shown in Scheme 3 , we have use here the methylester derivatives of four different amino acids, phenylglycine $(\mathrm{R}=\mathrm{Ph})$, phenylalanine $(\mathrm{R}=\mathrm{Bz})$, valine $(\mathrm{R}=\mathrm{iPr})$ and leucine $(\mathrm{R}=\mathrm{iBu})$. The ureido intermediates $2-\mathrm{R}$ were formed in good yields (67 to $74 \%$ ) from the reaction of the amino acid methylester hydrochloride with potassium cyanate in water at room temperature. ${ }^{33}$ Being aware of the racemisation problems reported earlier, an optimization of the cyclization conditions was conducted on the phenylalanine ureido derivative $(\mathrm{R}=\mathrm{Bz})$. Conducting the cyclization step in basic medium with sterically hindered amines such as DMAP or NEt 3 as reported, led however to the racemised hydantoins, as shown by HPLC. A similar optimization of the cyclisation step, but under acidic conditions, has been also reported by Dakin et $\mathrm{al},{ }^{3 \mathrm{~b}}$ by varying the experimental conditions (nature, concentration of acid and reaction time) and monitoring the optical activity of the final hydantoin product. Based on this study, we used $2 \mathrm{~N} \mathrm{HCl}$ and a minimum reflux time, allowing for a complete conversion of the four different ureas $2-\mathrm{R}$ to the corresponding hydantoins 3 -R (in 59-89\% yields) while maintaining the initial optical purity.

The next dibromation step was performed as described elsewhere ${ }^{34}$ for achiral hydantoins, by neutralization of 3-R with two equiv. $\mathrm{KOH}$ and reaction with dibromine at $10^{\circ} \mathrm{C}$. The dibromohydantoins 1-R were obtained in excellent yields (90-94\%) but only with $\mathrm{R}=\mathrm{Ph}$, iPr and $\mathrm{iBu}$, while 5-benzylhydantoin 3 -Bz was degraded under these conditions.
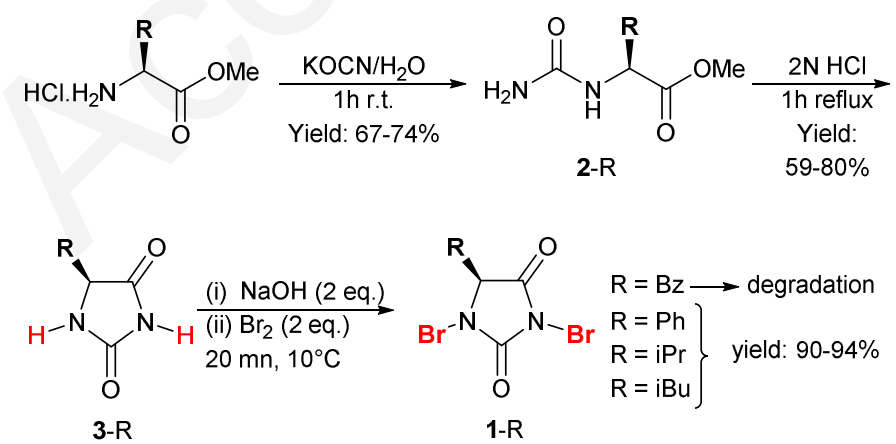

Scheme 3 Synthetic path to the chiral dibromohydantoins. 


\section{Halogen bonding in the pyridine adducts}

The co-crystallisation of achiral DBH with the electron-rich pyridines such as pyridine itself, 4-picoline, or 4-dimethylaminopyridine did not afford the expected adducts. Bromine-free dimethylhydantoin was recovered. With picoline, we could only isolate crystals of 4methylpyridinum bromide. On the other hand, the pyridines substituted in para position with electron-withdrawing substituents $\left(-\mathrm{CN},-\mathrm{CF}_{3},-\mathrm{CO}_{2} \mathrm{Me}\right)$ afforded systematically a 1:1 adduct (Fig. 1), despite the presence of two equivalents pyridine in the solution before crystallisation by vapour diffusion.
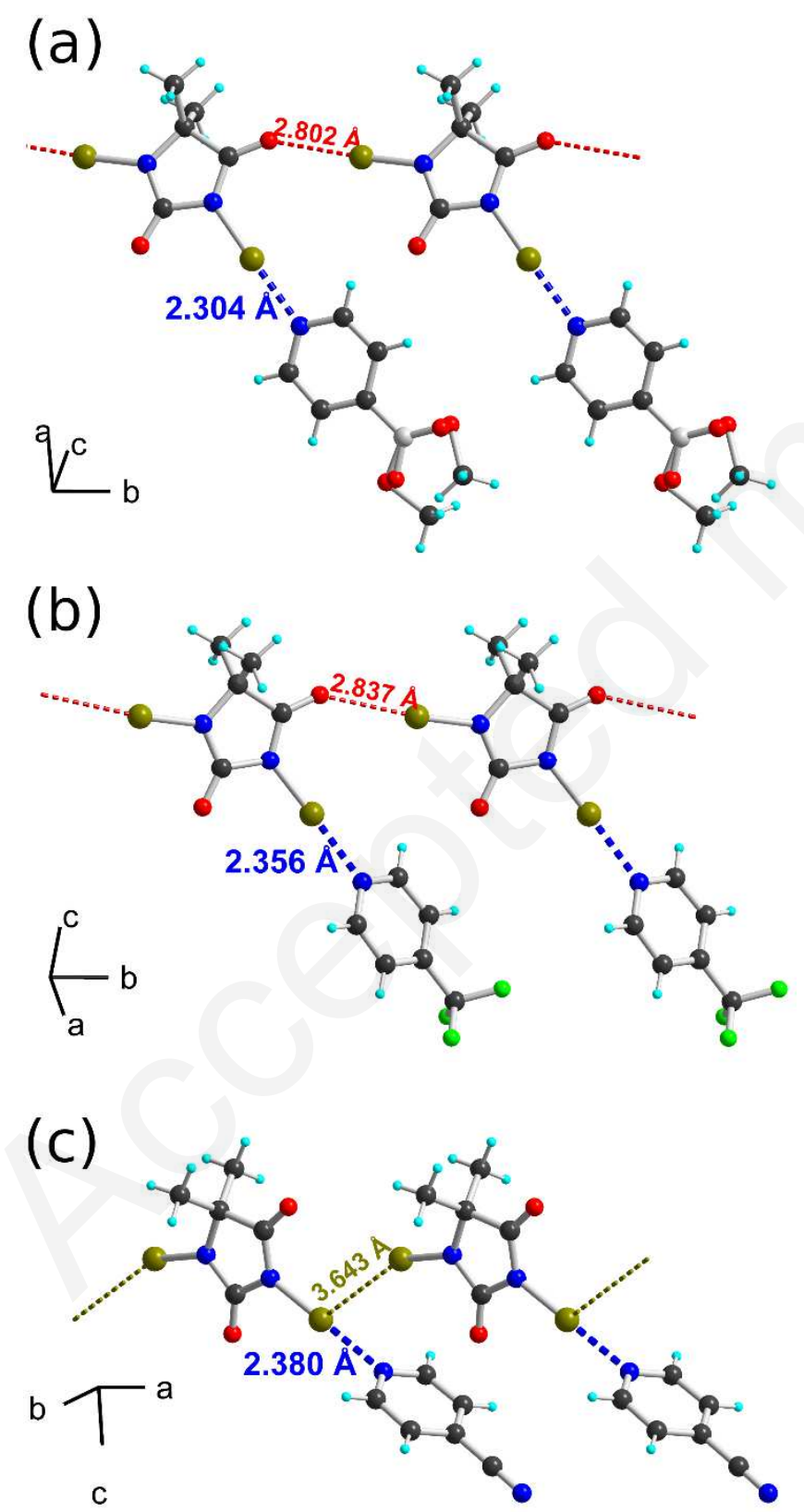

Fig. 1. Detail of the halogen bond interactions in the $1: 1$ adducts between DBH and respectively (a) methyisonicotinate, (b) 4-trifluoromethylpyridine and (c) 4-cyanopyridine. 
$\mathrm{DBH} \bullet\left[\mathrm{Py}-\mathrm{CO}_{2} \mathrm{Me}\right]$ crystallises in the triclinic system, space group $P \overline{1}$, with one halogen-bonded monoadduct in general position in the unit cell (Fig. 1a). The imidic bromine atom is halogen bonded to the nitrogen atom of methylisonicotinate while the other bromine atom in amidic position is halogen bonded to one oxygen atom of a neighbouring molecule. Note the disorder of the ester group on two positions with a 75:25 distribution. Relevant bond distances for these two intermolecular interactions are collected in Table 1, and compared with the sum of the van der Waals radii $\left(\mathrm{r}_{\mathrm{X}}, \mathrm{r}_{\mathrm{Y}}\right)$ of interacting atoms $(\mathrm{X}, \mathrm{Y})$ to define a socalled reduction ratio $(R R)$, i.e. $d(X \bullet \bullet Y) /\left(r_{X}+r_{Y}\right)$.

$\mathrm{DBH} \cdot\left[\mathrm{Py}-\mathrm{CF}_{3}\right]$ crystallises in the monoclinic system, space group $\mathrm{P} 2{ }_{1} / \mathrm{c}$ with one $\mathrm{XB}$ monoadduct in general position in the unit cell (Figure 1b). Intermolecular interactions parallel those observed above with a strong $\mathrm{Br} \bullet \bullet \mathrm{N}_{\mathrm{Py}}$ interaction involving the imidic bromine atom and a weaker Brø•O interaction with the amidic bromine atom.

The situation is slightly different in $\mathrm{DBH} \bullet[\mathrm{Py}-\mathrm{CN}]$. It crystallises in the monoclinic system, space group $\mathrm{C} 2 / \mathrm{m}$ with the $\mathrm{XB}$ adduct located on a mirror plane containing the hydantoin core while the cyanopyridine is perpendicular to this plane. This adduct crystallises with one 1,2-dichloroethane molecule, located on a $2 / \mathrm{m}$ position, hence the exact formulation $\mathrm{DBH} \bullet[\mathrm{Py}-\mathrm{CN}] \bullet\left(\mathrm{ClH}_{2} \mathrm{C}-\mathrm{CH}_{2} \mathrm{Cl}\right)_{0.5}$. Furthermore, besides the strong $\mathrm{Br} \bullet \bullet \mathrm{N}_{\mathrm{Py}}$ halogen bond involving the imidic bromine atom, the other amidic bromine atom is not halogen bonded to an oxygen atom as observed above with $\mathrm{Py}-\mathrm{CO}_{2} \mathrm{Me}$ and $\mathrm{Py}-\mathrm{CF}_{3}$, but is almost at van der Waals contact with a neighbouring bromine atom. The corresponding reduction ration for this Brø•Br interaction amounts indeed to 0.985 .

At last, the pyrazine adduct involves two DBH molecules for one pyrazine, located in an inversion centre. Halogen bonding Br $\bullet \cdot \mathrm{N}$ interactions involve the imidic bromine atom while the amidic bromine is bonded to the oxygen atom of a neighbouring DBH molecule (Fig. 2). 


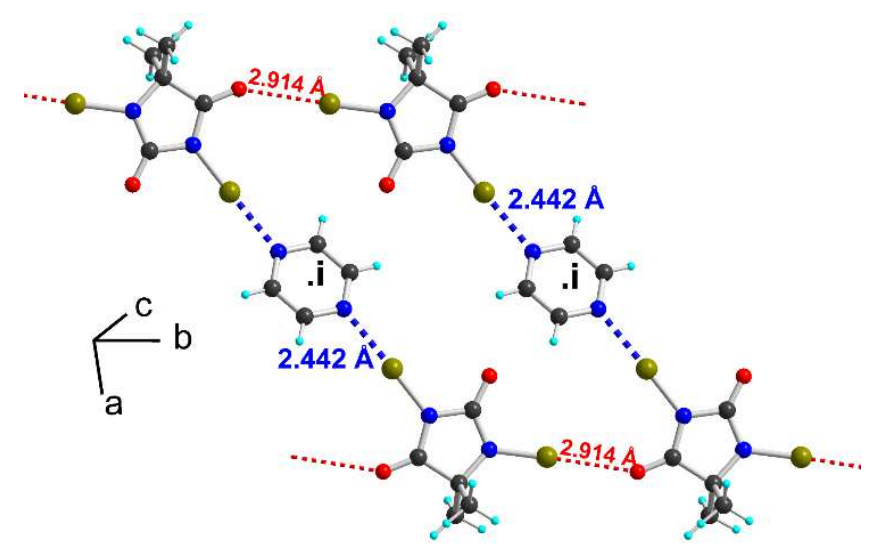

Fig. 2 Detail of the halogen bond interactions (blue and red dotted lines) in the adduct $(\mathrm{DBH})_{2} \bullet$ Pyrazine.

Table 1 Relevant bond distances involving the imidic and amidic bromide atoms of the dibromohydantoins $\mathrm{DBH}$ and the chiral 1-iBu in their pyridines (or pyrazine) adducts. The reduction ratio ( $R R$, see text for definition) are based on Bondi's values of van des Waals radii, $r_{B r}=1.85 \AA, r_{N}=$ $1.55 \AA$, ro $=1.52 \AA$.

\begin{tabular}{|c|c|c|c|c|c|c|}
\hline Lewis base & $\begin{array}{l}\text { Intramol. dist. } \\
\mathrm{N}-\mathrm{Br}_{\text {imidic }}(\AA)\end{array}$ & $\begin{array}{l}\mathrm{Br}_{\text {imidic }} \bullet \bullet \mathrm{N}_{\text {Py }} \\
\text { dist. }(\AA)\end{array}$ & $\mathrm{RR}(\mathrm{BrN})$ & $\begin{array}{l}\text { Intramol. dist. } \\
\mathrm{N}-\mathrm{Br}_{\text {amidic }}(\AA)\end{array}$ & $\begin{array}{l}\mathrm{Br}_{\text {amidic }} \bullet \bullet Y \\
\text { dist. }(\AA)\end{array}$ & $\mathrm{RR}(\mathrm{BrY})$ \\
\hline \multicolumn{7}{|l|}{ With DBH: } \\
\hline Pyrazine & $1.890(6)$ & $2.442(8)$ & 0.718 & $1.847(4)$ & $2.914(4), Y=O$ & 0.865 \\
\hline $\mathrm{Py}-\mathrm{CN}$ & $1.917(7)$ & $2.380(7)$ & 0.700 & $1.832(6)$ & $3.643(6), \mathrm{Y}=\mathrm{Br}$ & 0.985 \\
\hline $\mathrm{Py}-\mathrm{CF}_{3}$ & $1.908(4)$ & $2.356(4)$ & 0.693 & $1.850(3)$ & $2.837(2), \mathrm{Y}=\mathrm{O}$ & 0.842 \\
\hline $\mathrm{Py}-\mathrm{CO}_{2} \mathrm{Me}$ & $1.932(7)$ & $2.304(8)$ & 0.678 & $1.849(4)$ & $2.802(4), Y=O$ & 0.831 \\
\hline \multicolumn{7}{|l|}{ With 1-iBu: } \\
\hline $\mathrm{Py}-\mathrm{CO}_{2} \mathrm{Me}$ & $1.930(3)$ & $2.306(3)$ & 0.678 & $1.850(3)$ & $2.898(3)$ & 0.860 \\
\hline With DIH: ${ }^{a}$ & $\mathrm{~N}-\mathrm{I}_{\text {imidic }}(\AA)$ & $\mathrm{I}_{\text {imidic }} \bullet \bullet \mathrm{N}_{\mathrm{Py}}(\AA)$ & $\mathrm{RR}(\mathrm{IN})$ & $\mathrm{N}-\mathrm{I}_{\text {amidic }}(\AA)$ & $\mathrm{I}_{\text {amidic }} \bullet \bullet \bullet \mathrm{O}$ & $\mathrm{RR}(\mathrm{IN})$ \\
\hline $\mathrm{Py}-\mathrm{CO}_{2} \mathrm{Me}$ & $2.137(6)$ & $2.398(6)$ & 0.679 & $2.051(5)$ & $2.720(4)$ & 0.777 \\
\hline
\end{tabular}

${ }^{\mathrm{a}}$ see Ref 27

The evolution of the halogen bond distances with the nature of the Lewis base XB acceptor is particularly interesting to discuss here. We first note that the stronger XB interaction involves the imidic bromine atom, as already observed in the analogous diiodohydantoin analog. ${ }^{27}$ The interaction is particularly strong, with RR values in the range $0.68-0.72$. Also, the interaction is stronger, i.e. the reduction ratio RR is smaller, with the more electron rich pyridines. The observed ranking, $\mathrm{Py}-\mathrm{CO}_{2} \mathrm{Me}>\mathrm{Py}-\mathrm{CF}_{3}>\mathrm{Py}-\mathrm{CN}>$ Pyrazine is fully consistent with our own earlier observations with diiodohydantoin adducts, ${ }^{27}$ as well as with other $\mathrm{pK}_{\mathrm{B}}$ scales established for examples with diiodine $\left(\mathrm{I}_{2}\right)$ as $\mathrm{XB}$ donor. ${ }^{35}$ The XB interaction also affects the dibromohydantoin itself as the intramolecular $\mathrm{N}-\mathrm{Br}_{\text {imidic }}$ distance increases as the bromine is 
involved in the strongest XB. Another interesting feature is the fact that the second, amidic bromine atom is not halogen bonded to a second pyridine (despite an excess of pyridine in the crystallisation process) but is halogen bonded to the carbonyl oxygen atom of a neighboring DBH molecule. This behaviour was already encountered with diodohydantoin (DIH) faced with these electron poor pyridines. ${ }^{27}$ It is associated to a strong polarization of the XB adduct following the setting of the strongest XB through the imidic bromine atom (Scheme 4). The partial negative charge which delocalizes on the DBH moiety deactivates the second amidic bromine atom while it increases simultaneously the negative charge of the carbonyl oxygen atoms. Last but not least, a comparison of the strength of the halogen bond, within the bromo and iodo adducts of methylisonicotinate, that is $\mathrm{DBH} \bullet\left[\mathrm{Py}-\mathrm{CO}_{2} \mathrm{Me}\right]$ and $\mathrm{DIH} \cdot\left[\mathrm{Py}-\mathrm{CO}_{2} \mathrm{Me}\right]$ can be obtained from the comparison of the reduction ratios. As shown in Table 1, the $\mathrm{RR}(\mathrm{Br}, \mathrm{N})$ and $\mathrm{RR}(\mathrm{I}, \mathrm{N})$ are essentially the same, 0.678 vs. 0.679 , in contradiction to the general rule that states that halogen bonding is systematically stronger with iodine than with bromine. A similar behaviour has been mentioned by Rissanen et al. ${ }^{36}$ in the haloniumpyridine $[\mathrm{Py}-\mathrm{X}-\mathrm{Py}]^{+}$cations, ${ }^{37,38}$ where the reduction ratio for the $\mathrm{N} \bullet \bullet \mathrm{Br}$ bonds $(0.63)$ is even smaller than for the N•••I bonds (0.65). This striking result tends to indicate that the $\mathrm{XB}(\mathrm{I})>\mathrm{XB}(\mathrm{Br})$ rule only holds for "normal", i.e. relatively weak halogen bonds. In the extreme situations mentioned above, the halogen bonds exhibit a sizeable covalent character, and the covalent bond strengths for $\mathrm{N}-\mathrm{I}$ and $\mathrm{N}-\mathrm{Br}$ bonds are indeed in reverse order, $\mathrm{N}-\mathrm{Br}$ $\left(67 \mathrm{kcal} \mathrm{mol}^{-1}\right)>\mathrm{N}-\mathrm{I}\left(38 \mathrm{kcal} \mathrm{mol}^{-1}\right)$.

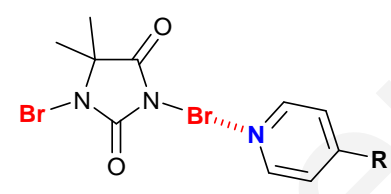

Neutral XB form

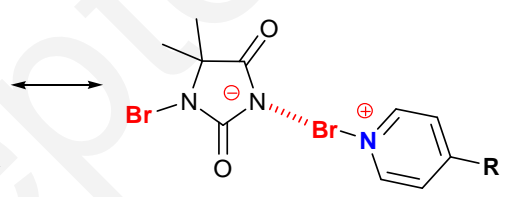

Ionic XB form

Scheme 4 Polarization on the XB adduct $\mathrm{DBH} \cdot[\mathrm{Py}-\mathrm{R}]$.

As mentioned in the Introduction, the interest of such diodo- or dibromohydantoins also lies in their ability to potentially provide chiral, enantiopure ditopic halogen bond donors. For that purpose, the chiral hydantoins 3-R derived from $(S)$-phenylglycine $(\mathrm{R}=\mathrm{Ph})$, phenylalanine $(\mathrm{R}=\mathrm{Bz})$, valine $(\mathrm{R}=\mathrm{iPr})$ and leucine $(\mathrm{R}=\mathrm{iBu})$ were prepared and the corresponding dibromo derivatives 1-R were isolated with, as substitution pattern on the 5 position, one hydrogen and one $\mathrm{R}$ group, $\mathrm{R}=\mathrm{Ph}, \mathrm{iPr}$ and $\mathrm{iBu}$. Note that $\mathrm{1}-\mathrm{Bz}$ could not be isolated under these conditions. Our first attempts to co-crystallise the three novel chiral 
halogen bond donors with different pyridines afforded a crystalline phase from the association of the $\mathbf{1}-\mathrm{iBu}$ with methylisonicotinate, formulated as $[\mathbf{1}-\mathrm{iBu}] \cdot\left[\mathrm{Py}-\mathrm{CO}_{2} \mathrm{Me}\right]$. It crystallises in the orthorhombic system, chiral space group $\mathrm{P} 2{ }_{1} 2_{1} 2_{1}$, with one adduct in general position in the unit cell (Fig. 3). The halogen bonded motifs parallels those observed above with the achiral $\mathrm{DBH}$, with the imidic bromine atom engaged in $\mathrm{XB}$ with the pyridinic nitrogen while the other amidic bromine atom links to the carbonyl oxygen atom of a neighbouring molecule by translation along the $b$ axis. The structural characteristics of the strongest $\mathrm{Br} \bullet \bullet \mathrm{N}_{\mathrm{Py}} \mathrm{XB}$ interaction (Table 1) are very close to those observed within the adduct of achiral DBH with

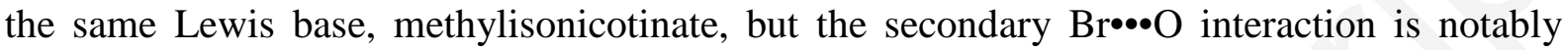
weakened ( $2.898 \AA$ instead of $2.802 \AA$ ). It is associated with a lowered directionality, with the Br atom lying $1.31 \AA$ above the basal plane defined by the neighbouring heterocycle along $b$, while within the adduct of achiral DBH, this bromine atom is only at $0.36 \AA$ above the basal plane of the neighbouring molecule.

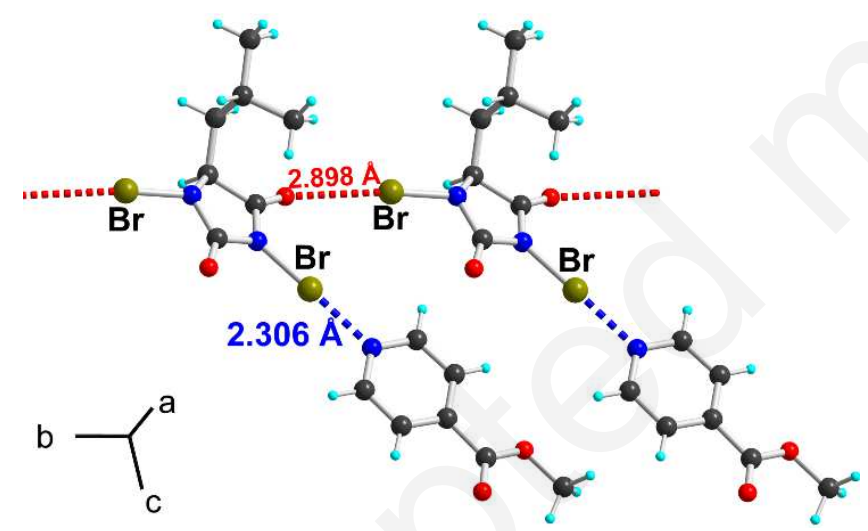

Fig. 3 Detail of the halogen bond interactions in the $[1-\mathrm{iBu}] \cdot\left[\mathrm{Py}-\mathrm{CO}_{2} \mathrm{Me}\right]$ adduct.

In conclusion, we have demonstrated that N,N'-dibromohydantoin derivatives can act as strong halogen bond donors, comparable indeed to the corresponding iodo derivatives. At variance with them however, the reactivity of dibromohydantoins hinders the isolation of Lewis base adducts with the most electron rich pyridines (pyridine, 4-picoline, 4dimethylaminopyridine) but allows for the isolation of $\mathrm{XB}$ adducts with the pyridines bearing electron-withdrawing substituents $\left(\mathrm{CO}_{2} \mathrm{Me}, \mathrm{CF}_{3}, \mathrm{CN}\right)$ or with pyrazine, with only the imidic bromine atom engaged in the $\mathrm{XB}$ interaction with the pyridinic nitrogen atom. The isolation of the chiral $\mathrm{N}, \mathrm{N}$-dibromo hydantoins $1-\mathrm{R}(\mathrm{R}=\mathrm{Ph}, \mathrm{iPr}, \mathrm{iBu})$ opens many perspectives in crystal engineering, for the elaboration of chiral networks, as demonstrated here by a first 
pyridine adduct involving the (S)-5-isobutyl-N,N'-dibromohydantoin 1-iBu and methyl isonicotinate.

\section{Experimental}

General. ${ }^{1} \mathrm{H}$ and ${ }^{13} \mathrm{C}$ spectra were collected on a BRUKER AV $300\left({ }^{1} \mathrm{H}: 300 \mathrm{MHz},{ }^{13} \mathrm{C}\right.$ : 75,5 MHz). Chemical shifts $\delta$ are expressed in part per million (ppm), vs. the deuterated solvent used as reference, such as $\mathrm{d}^{6}$-DMSO $\left({ }^{1} \mathrm{H}\right.$ NMR $\delta 2.50 \mathrm{ppm},{ }^{13} \mathrm{C}$ NMR $\left.\delta 128.06 \mathrm{ppm}\right)$. The following abbreviations were used to describe signal multiplicity: bs broad singlet, $s$ singlet, $\mathrm{d}$ doublet, $\mathrm{t}$ triplet, q quadruplet, $\mathrm{m}$ multiplet, dd doublet of doublet, ddd doublet of doublet of doublet. Analytical thin layer chromatography was performed with MACHEREYNAGEL 60F254 plates (Silica on aluminum foil 60F254, 60/20 mm) and the plates were revealed by Ninhydrin solution and read with UV fluorescence at $254 \mathrm{~nm}$. Chiral HPLC was performed on a Varian Prep Star 218 equipped with Photodiodes Varian Pro Star 330. An analytical Chiracel ${ }^{\circledR}$ OD-H $(4,6 \times 250 \mathrm{~mm}, 5 \mu \mathrm{m})$ column was used with as eluent an hexane/isopropanol mixture, at $1 \mathrm{~mL} \cdot \mathrm{min}^{-1}$ flow with solutions of $5 \mathrm{mg}$ sample for $500 \mu \mathrm{L}$ isopropanol. Absolute optical rotations $[\alpha]_{\mathrm{D}}$ were determined on a Perkin Elmer 341 polarimeter using the $\mathrm{Na}$ line at $589 \mathrm{~nm}$ according to $[\alpha]_{D}=\frac{\alpha_{\exp }}{l \times c}$ where is $\alpha_{\exp }$ is the observed rotation angle, $l$ the length of optical path $(10 \mathrm{~cm})$ and $c$ the concentration (in $\left.\mathrm{g} \cdot \mathrm{mL}^{-1}\right)$.

General procedure for the preparation of the chiral ureas (2-R). In a $100 \mathrm{~mL}$ flask, the aminoester hydrochloride ( $2 \mathrm{~g}$ ) is dissolved in water (170 equiv.) and KOCN (1.02 equiv.) is added. The mixture is stirred for one hour at room temperature.

2-Ph. L-Phenylglycine methyl ester hydrochloride (2 g, $9.92 \mathrm{mmol}), \mathrm{KOCN}$ (845 mg, 1.02 eq), $\mathrm{H}_{2} \mathrm{O}$ (7 mL, 170 equiv.). The white precipitate is filtered and washed with cold water, and then dried over $\mathrm{KOH}$ in vacuum. Yield: $1.47 \mathrm{~g}(71 \%)$. M.p. $136-137{ }^{\circ} \mathrm{C} .{ }^{1} \mathrm{H}$ NMR (DMSO$\left.\mathrm{d}_{6}, 300 \mathrm{MHz}\right) \delta 3.62\left(\mathrm{~s}, 3 \mathrm{H}, \mathrm{COOCH}_{3}\right), 5.25\left(\mathrm{~d},{ }^{3} \mathrm{~J}=6,0 \mathrm{~Hz}, 1 \mathrm{H}, \mathrm{CH} \alpha\right), 5.69\left(\mathrm{ls}, 2 \mathrm{H}, \mathrm{NH}_{2}\right)$, $6.86\left(\mathrm{~d},{ }^{3} \mathrm{~J}=9 \mathrm{~Hz}, 1 \mathrm{H}, \mathrm{NH}\right), 7.36\left(\mathrm{~m}, 5 \mathrm{H}, \mathrm{H}_{\mathrm{Ar}}\right) .{ }^{13} \mathrm{C}$ NMR $\left(\mathrm{DMSO}_{-} \mathrm{d}_{6}, 75.5 \mathrm{MHz}\right) \delta 52.57$

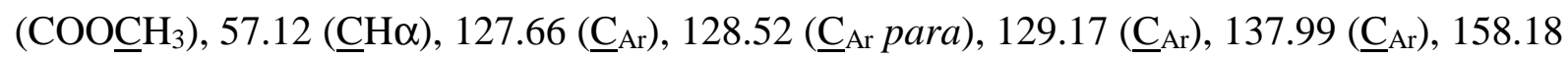

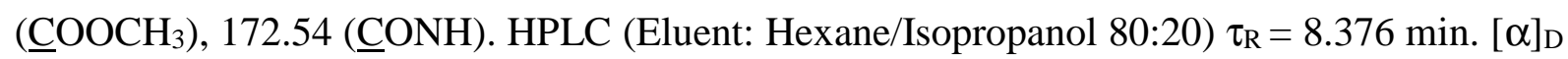
$\left(\mathrm{c}=9 \cdot 9 \cdot 10^{-4} \mathrm{~g} \mathrm{~mL}^{-1}, \mathrm{EtOH}\right)=+147.5^{\circ}$. 
2-Bz. L-Phenylalanine methyl ester hydrochloride (2 g, $9.97 \mathrm{mmol})$, KOCN (753 mg, 1.02 eq), $\mathrm{H}_{2} \mathrm{O}$ (30 mL, 170 equiv.). The solution is extracted with AcOEt. The organic phases are dried over $\mathrm{Na}_{2} \mathrm{SO}_{4}$, filtered and concentrated under reduced pressure. Yield: $1.36 \mathrm{~g}(67 \%)$. M.p. $102-103{ }^{\circ} \mathrm{C} .{ }^{1} \mathrm{H}$ NMR (DMSO-d $\left.6,300 \mathrm{MHz}\right) \delta 2.92\left(\mathrm{qd},{ }^{3} J_{l}=13.7 \mathrm{~Hz},{ }^{3} J_{2}=6.8 \mathrm{~Hz}, 2 \mathrm{H}\right.$, $\left.\mathrm{Ph}-\underline{\mathrm{CH}_{2}}\right), 3.60\left(\mathrm{~s}, 3 \mathrm{H}, \mathrm{COOCH}_{3}\right), 4.38\left(\mathrm{td},{ }^{3} \mathrm{~J}_{1}=8.1 \mathrm{~Hz},{ }^{3} \mathrm{~J}_{2}=5.6 \mathrm{~Hz}, 1 \mathrm{H}, \mathrm{CH \alpha}\right), 5.63(\mathrm{bs}, 2 \mathrm{H}$, $\left.\mathrm{NH}_{2}\right), 6.28\left(\mathrm{~d},{ }^{3} \mathrm{~J}=8.2 \mathrm{~Hz}, 1 \mathrm{H}, \mathrm{NH}\right), 7.25\left(\mathrm{~m}, 5 \mathrm{H}, \mathrm{H}_{\mathrm{Ar}}\right) .{ }^{13} \mathrm{C} \mathrm{NMR}\left(\mathrm{DMSO}-\mathrm{d}_{6}, 75.5 \mathrm{MHz}\right) \delta$ $38.06\left(\mathrm{Ph}-\underline{\mathrm{CH}}_{2}\right), 52.10\left(\mathrm{COOC}_{3}\right), 54.33(\underline{\mathrm{CH}} \alpha), 126.97$ (드사 para $), 128.70\left(\underline{\mathrm{C}}_{\mathrm{Ar}}\right), 129.58\left(\underline{\mathrm{C}}_{\mathrm{Ar}}\right)$, $137.60\left(\underline{\mathrm{C}}_{\mathrm{Ar}}\right), 158.41\left(\underline{\mathrm{COOCH}}_{3}\right), 173.51(\underline{\mathrm{CONH}}) . \mathrm{HPLC}$ (Eluent Hexane/Isopropanol 80:20) $\tau_{\mathrm{R}}=8.584 \min .[\alpha]_{\mathrm{D}}\left(\mathrm{c}=1.06 \cdot 10^{-3} \mathrm{~g} \cdot \mathrm{mL}^{-1}, \mathrm{EtOH}\right)=+28.3^{\circ}$.

2-iPr. L-Valine methyl ester hydrochloride (2 g, 13 mmol), KOCN (973 mg, 1.02 equiv.), $\mathrm{H}_{2} \mathrm{O}$ (36 mL, 170 equiv.). The solution is extracted with AcOEt. The organic phases are dried over $\mathrm{Na}_{2} \mathrm{SO}_{4}$, filtered and concentrated under reduced pressure. Yield 1.63 g (74 \%). M.p. 99$100{ }^{\circ} \mathrm{C} .{ }^{1} \mathrm{H}$ NMR (DMSO-d $\left.6,300 \mathrm{MHz}\right) 0.85\left(\mathrm{t},{ }^{3} \mathrm{~J}=7.2 \mathrm{~Hz}, 6 \mathrm{H}, 2 \mathrm{CH}_{3}\right), 1.96(\mathrm{~m}, 1 \mathrm{H}$, $\left.\mathrm{C} \underline{\mathrm{H}}\left(\mathrm{CH}_{3}\right)_{2}\right), 3.63(\mathrm{~s}, 3 \mathrm{H}, \mathrm{COOCH} 3), 4.05\left(\mathrm{dd},{ }^{3} J_{1}=8.8 \mathrm{~Hz},{ }^{3} J_{2}=5.5 \mathrm{~Hz}, 1 \mathrm{H}, \mathrm{CH} \alpha\right), 5.61(\mathrm{ls}$, $\left.2 \mathrm{H}, \mathrm{NH}_{2}\right), 6,29\left(\mathrm{~d},{ }^{3} \mathrm{~J}=8,8 \mathrm{~Hz}, 1 \mathrm{H}, \mathrm{NH}\right) .{ }^{13} \mathrm{C}$ NMR (DMSO-d $\left.6,75.5 \mathrm{MHz}\right) \delta 18.27$ $\left(\mathrm{CH}\left(\underline{\mathrm{CH}}_{3}\right)_{2}\right), 19.43\left(\mathrm{CH}\left(\underline{\mathrm{CH}}_{3}\right)_{2}\right), 30.83\left(\underline{\mathrm{CH}}\left(\mathrm{CH}_{3}\right)_{2}\right), 51.92\left(\mathrm{COOCH}_{3}\right), 58.0(\underline{\mathrm{CH} \alpha}), 158.86$

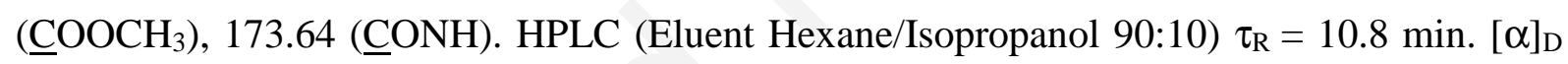
$\left(\mathrm{c}=1.11 .10^{-3} \mathrm{~g} \cdot \mathrm{mL}^{-1}, \mathrm{EtOH}\right)=-6.30^{\circ}$.

2-iBu. L-Leucine methyl ester hydrochloride (2 g, 12 mmol), KOCN (1.26 g, 1.02 equiv.), $\mathrm{H}_{2} \mathrm{O}$ (47 mL, 170 eq). The solution is extracted with AcOEt. The organic phases are dried over $\mathrm{Na}_{2} \mathrm{SO}_{4}$, filtered and concentrated under reduced pressure. Yield $1.53 \mathrm{~g}(68 \%)$. M.p. 67$68{ }^{\circ} \mathrm{C} .{ }^{1} \mathrm{H}$ NMR (DMSO-d $\left.6,300 \mathrm{MHz}\right) \delta 0.87\left(2 \mathrm{~d},{ }^{3} \mathrm{~J}_{1}=6.7 \mathrm{~Hz},{ }^{3} \mathrm{~J}_{2}=6.6 \mathrm{~Hz}, 6 \mathrm{H}, 2 \mathrm{CH}_{3}\right), 1.43$ $\left(\mathrm{t},{ }^{3} \mathrm{~J}=7,5 \mathrm{~Hz}, 2 \mathrm{H}, \mathrm{CH}_{2}\right), 1.61\left(\mathrm{~m}, 1 \mathrm{H}, \underline{\mathrm{CH}}\left(\mathrm{CH}_{3}\right)_{2}\right), 3.61\left(\mathrm{~s}, 3 \mathrm{H}, \mathrm{COOC} \underline{\mathrm{H}_{3}}\right), 4.14\left(\mathrm{q},{ }^{3} \mathrm{~J}=7,7\right.$ $\mathrm{Hz}, 1 \mathrm{H}, \mathrm{CH} \alpha$ ), 5.55 (bs, 2H, NH ), 6.30 (d, $\left.{ }^{3} \mathrm{~J}=8.2 \mathrm{~Hz}, 1 \mathrm{H}, \mathrm{NH}\right) .{ }^{13} \mathrm{C}$ NMR (DMSO-d $6,75.5$ $\mathrm{MHz}) \delta 21.95\left(\mathrm{CH}\left(\underline{\mathrm{CH}}_{3}\right)_{2}\right), 23.19\left(\mathrm{CH}\left(\underline{\mathrm{CH}}_{3}\right)_{2}\right), 24.71\left(\underline{\mathrm{CH}}\left(\mathrm{CH}_{3}\right)_{2}\right), 41.24\left(\mathrm{CH}_{2}\right) 51.21$ $\left(\mathrm{COOCH}_{3}\right), \quad 52.07 \quad(\underline{\mathrm{CH}} \alpha), \quad 158.63 \quad\left(\underline{\mathrm{COOCH}}_{3}\right), \quad 174.71 \quad(\underline{\mathrm{CONH}}) . \quad$ HPLC $\quad$ (Eluent Hexane/Isopropanol 90:10) $\tau_{\mathrm{R}}=10.381 \mathrm{~min} .[\alpha]_{\mathrm{D}}\left(\mathrm{c}=1,03 \cdot 10^{-3} \mathrm{~g} \mathrm{~mL}^{-1}, \mathrm{EtOH}\right)=-17,47^{\circ}$.

General procedure for the preparation of the chiral hydantoins (3-R). The above prepared ureas $2-\mathrm{R}$ are suspended in $2 \mathrm{~N} \mathrm{HCl}$ and stirred at reflux for one hour. ${ }^{31 \mathrm{~b}}$ 
3-Ph. With 2-Ph (504.6 mg, $2.4 \mathrm{mmol})$ and $\mathrm{HCl} 2 \mathrm{~N}$ (10 mL, 8.3 eq). The filtered residue is washed with cold water and dried under vacuum over KOH. Yield: $250 \mathrm{mg}$ (59\%). M. p. 177-178 ${ }^{\circ} \mathrm{C}\left(\operatorname{Litt}^{[31 \mathrm{a}]} 177-178{ }^{\circ} \mathrm{C}\right) .{ }^{1} \mathrm{H}$ NMR (DMSO-d6, $\left.300 \mathrm{MHz}\right) \delta 5.16(\mathrm{~s}, 1 \mathrm{H}, \mathrm{CH}), 7.37$

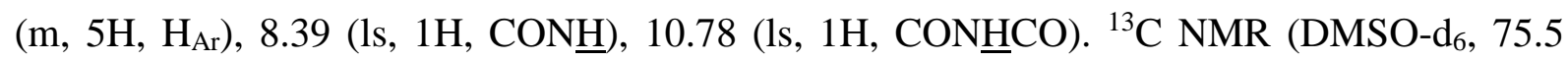
$\mathrm{MHz}) \delta(\mathrm{ppm}): 61.64(\underline{\mathrm{CH}} \alpha), 127.15\left(\mathrm{C}_{\mathrm{Ar}}\right), 128.69\left(\mathrm{C}_{\mathrm{Ar}}\right.$ para $), 129.10\left(\mathrm{C}_{\mathrm{Ar}}\right), 136.50\left(\mathrm{C}_{\mathrm{Ar}}\right)$, $157.94(\underline{\mathrm{CONH}}), 174.64(\mathrm{NH} \underline{\mathrm{CONH}})$. HPLC (Eluent Hexane/Isopropanol 80:20) $\tau_{\mathrm{R}}=15 \mathrm{~min}$ $($ ee $99.7 \%) .[\alpha]_{\mathrm{D}}\left(\mathrm{c}=0.98 .10^{-3} \mathrm{~g} \mathrm{~mL}^{-1}, \mathrm{EtOH}\right)=+103.06^{\circ}\left(\mathrm{Litt}^{[39]}:+112^{\circ}, \mathrm{c}=0.20 \mathrm{~g} \cdot \mathrm{mL}^{-1}\right.$, $\mathrm{EtOH})$.

3-Bz. With 2-Bz (1.013 g, $4.6 \mathrm{mmol})$ and $\mathrm{HCl} 2 \mathrm{~N}$ (19 mL, 8.3 equiv.). The solution is extracted with AcOEt. The combined organic phases are dried over $\mathrm{Na}_{2} \mathrm{SO}_{4}$, filtered and concentrated to dryness. Yield: $764 \mathrm{mg}(87 \%)$. M.p. $175-176{ }^{\circ} \mathrm{C}$ (Litt. $\left.{ }^{[30 a]} 187-189{ }^{\circ} \mathrm{C}\right) .{ }^{1} \mathrm{H}$ NMR (DMSO-d $6,300 \mathrm{MHz}) \delta 2.93\left(\mathrm{~m}, 2 \mathrm{H}, \mathrm{CH}_{2}\right), 4,33\left(\mathrm{td},{ }^{3} J_{1}=3 \mathrm{~Hz},{ }^{3} J_{2}=6 \mathrm{~Hz}, 1 \mathrm{H}, \mathrm{CH}\right)$, $7.25\left(\mathrm{~m}, 5 \mathrm{H}, \mathrm{H}_{\mathrm{Ar}}\right), 7.90(\mathrm{ls}, 1 \mathrm{H}, \mathrm{CONH}), 10.41$ (1s, 1H, CONHCO). ${ }^{13} \mathrm{C}$ NMR(DMSO-d $6,75.5$ $\mathrm{MHz}) \delta 36.89\left(\underline{\mathrm{CH}}_{2}\right), 58.84(\underline{\mathrm{CH}}), 127.09\left(\mathrm{C}_{\mathrm{Ar}}\right.$ para $), 128.52\left(\mathrm{C}_{\mathrm{Ar}}\right), 130.17\left(\mathrm{C}_{\mathrm{Ar}}\right), 136.09$ $\left(\mathrm{C}_{\mathrm{Ar}}\right), 157.56(\underline{\mathrm{CONH}}), 175.61(\mathrm{NH} \underline{\mathrm{CONH}})$. HPLC (Eluent Hexane/Isopropanol 80:20) $\tau_{\mathrm{R}}=$ $8.536 \min (\mathrm{ee} 99.8 \%) .[\alpha]_{\mathrm{D}}\left(\mathrm{c}=0.97 .10^{-3} \mathrm{~g} \mathrm{~mL}^{-1}, \mathrm{EtOH}\right)=-98.97^{\circ}\left(\mathrm{Litt}^{[40]}-96^{\circ} ; \mathrm{c}=0.20\right.$ g.mL $\left.\mathrm{mL}^{-1}, \mathrm{EtOH}\right)$.

3-iPr. With 2-iPr (1.047 g, $6.0 \mathrm{mmol})$ and $\mathrm{HCl} 2 \mathrm{~N}$ (30 mL, 8.3 equiv.). The solution is extracted with AcOEt. The combined organic phases are dried over $\mathrm{Na}_{2} \mathrm{SO}_{4}$, filtered and concentrated to dryness. Yield: $688 \mathrm{mg}(81 \%)$. M. p. $131-132{ }^{\circ} \mathrm{C}$ (Litt. $\left.{ }^{[31 \mathrm{a}]}{ }^{144-146}{ }^{\circ} \mathrm{C}\right) .{ }^{1} \mathrm{H}$ NMR (DMSO-d $6,300 \mathrm{MHz}) \delta 0.80\left(\mathrm{~d},{ }^{3} \mathrm{~J}=6 \mathrm{~Hz}, 3 \mathrm{H}, \mathrm{CH}_{3}\right), 0.94\left(\mathrm{~d},{ }^{3} \mathrm{~J}=6 \mathrm{~Hz}, 3 \mathrm{H}, \mathrm{CH}_{3}\right)$, $1.98\left(\mathrm{~m}, 1 \mathrm{H}, \mathrm{C} \underline{\mathrm{H}}\left(\mathrm{CH}_{3}\right)_{2}\right), 3.90\left(\mathrm{dd},{ }^{3} J_{1}=3 \mathrm{~Hz},{ }^{3} J_{2}=6 \mathrm{~Hz}, 1 \mathrm{H}, \mathrm{CH} \alpha\right), 7.89(\mathrm{ls}, 1 \mathrm{H}, \mathrm{CON} \underline{\mathrm{H}})$,

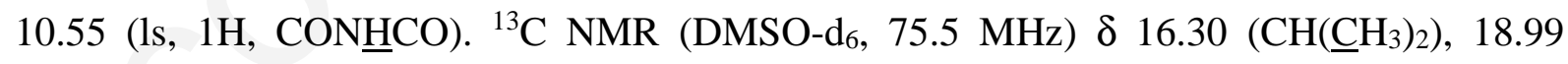

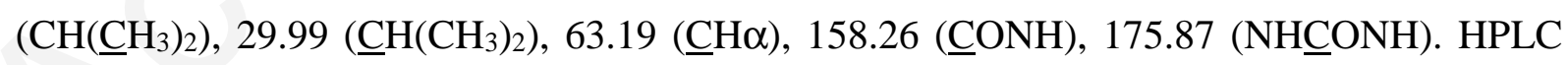
(Eluent Hexane/Isopropanol 90:10) $\tau_{\mathrm{R}}=10.541 \mathrm{~min}($ ee $100 \%) .[\alpha]_{\mathrm{D}}\left(\mathrm{c}=1.08 .10^{-3} \mathrm{~g} \mathrm{~mL}^{-1}\right.$, $\mathrm{EtOH})=-94.44^{\circ}\left(\right.$ Litt. $^{[40]}-94^{\circ}, \mathrm{c}=0.20$ g.mL $\left.{ }^{-1}, \mathrm{EtOH}\right)$

3-iBu. With 2-iBu (1.002 g, $5.3 \mathrm{mmol})$ and $\mathrm{HCl} 2 \mathrm{~N}$ (32 mL, 8.3 equiv.). The filtered residue is washed with cold water and dried under vacuum over KOH. Yield: $674 \mathrm{mg}$ (81\%). M.p. 213-214 ${ }^{\circ} \mathrm{C}$ (Litt. $\left.{ }^{[31 \mathrm{a}]} 213-214{ }^{\circ} \mathrm{C}\right) .{ }^{1} \mathrm{H}$ NMR (DMSO-d $\left.6,300 \mathrm{MHz}\right) \delta 0.88\left(2 \mathrm{~d},{ }^{3} J_{1}=6.6 \mathrm{~Hz}\right.$, $\left.{ }^{3} J_{2}=4.8 \mathrm{~Hz}, 6 \mathrm{H}, 2 \mathrm{CH}_{3}\right), 1.45\left(\mathrm{~m}, 2 \mathrm{H}, \mathrm{CH}_{2}\right), 4.00\left(\mathrm{ddd},{ }^{3} J_{1}=9.3 \mathrm{~Hz},{ }^{3} J_{2}=4.5 \mathrm{~Hz},{ }^{3} J_{3}=1.4 \mathrm{~Hz}\right.$, 
$1 \mathrm{H}, \mathrm{CH} \alpha), 8.00$ (1s, $1 \mathrm{H}, \mathrm{CON} \underline{\mathrm{H}}), 10.57$ (1s, 1H, CON$\underline{H C O}) .{ }^{13} \mathrm{C}$ NMR (DMSO-d $\left.6,75.5 \mathrm{MHz}\right)$ $\delta 21.89\left(\mathrm{CH}\left(\underline{\mathrm{CH}}_{3}\right)_{2}\right), 23.58\left(\mathrm{CH}\left(\underline{\mathrm{CH}}_{3}\right)_{2}\right), 24.58\left(\underline{\mathrm{CH}}\left(\mathrm{CH}_{3}\right)_{2}\right), 41.24\left(\underline{\mathrm{CH}}_{2}\right), 56.54(\underline{\mathrm{CH}} \alpha)$, $157.88(\underline{\mathrm{CONH}}), 176.95(\mathrm{NH} \underline{\mathrm{CONH}}) . \mathrm{HPLC}\left(\right.$ Eluent Hexane/Isopropanol 90:10) $\tau_{\mathrm{R}}=9.088$ $\min (\mathrm{ee}: 99 \%) \cdot[\alpha]_{\mathrm{D}}\left(\mathrm{c}=1.07 \cdot 10^{-3} \mathrm{~g} \cdot \mathrm{mL}^{-1}, \mathrm{EtOH}\right)=-78.5^{\circ}$.

General procedure for the preparation of the $N, N^{\prime}$-dibromohydantoins (1-R). In a $100 \mathrm{~mL}$ flask, hydantoin 3-R (200 mg) is suspended in water (111 equiv.) and the suspension cooled to $10^{\circ} \mathrm{C}$. $\mathrm{NaOH}(1 \mathrm{~N}$ in water, 2 equiv.) is added and the mixture stirred until complete dissolution. The flask is covered to work in the dark and $\mathrm{Br}_{2}$ (2 equiv.) is added dropwise. After stirring for $20 \mathrm{~min}$ at $10^{\circ} \mathrm{C}$, the resulting precipitate is filtered, washed with cold water and dried in vacuum over $\mathrm{KOH}$.

1-Ph. With 3-Ph (195 mg, $0.92 \mathrm{mmol}), \mathrm{NaOH} 1 \mathrm{~N}$ (2 mL, $2 \mathrm{mmol}), \mathrm{H}_{2} \mathrm{O}$ (2 mL, $0.11 \mathrm{~mol}, 111$ equiv.) and $\mathrm{Br}_{2}\left(102 \mu \mathrm{L}, 2 \mathrm{mmol}, 2\right.$ equiv.). Yield: $304 \mathrm{mg}$ (Yield 91\%). M. p. 108-109 ${ }^{\circ} \mathrm{C}$. ${ }^{1} \mathrm{H}$ NMR $\left(\mathrm{ACN}-\mathrm{d}_{3}, 300 \mathrm{MHz}\right) \delta 5.24(\mathrm{~s}, 1 \mathrm{H}, \mathrm{CH} \alpha), 7.60\left(\mathrm{~m}, 5 \mathrm{H}, \mathrm{H}_{\mathrm{Ar}}\right) .{ }^{13} \mathrm{C} \mathrm{NMR}\left(\mathrm{ACN}-\mathrm{d}_{3}\right.$, $75.5 \mathrm{MHz}) \delta 71,69(\underline{\mathrm{CH}} \alpha), 127,84\left(\mathrm{C}_{\mathrm{Ar}}\right), 129,15\left(\mathrm{C}_{\mathrm{Ar}}\right), 129,77\left(\mathrm{C}_{\mathrm{Ar}}\right.$ para $), 132,48\left(\mathrm{C}_{\mathrm{Ar}}\right)$, 154,45 (ㄷNBr), 168,69 (NBrCONBr). Elem. Anal. Calcd for $\mathrm{C}_{9} \mathrm{H}_{6} \mathrm{Br}_{2} \mathrm{~N}_{2} \mathrm{O}_{2}(\mathrm{M}=333.967 \mathrm{~g}$ $\left.\mathrm{mol}^{-1}\right) \mathrm{C}, 32.37 ; \mathrm{H}, 1.81$; N, 8.39\%. Found: C, 32.52; H, 2.41; N, 8.44\%. $[\alpha]_{\mathrm{D}}\left(\mathrm{c}=1,12.10^{-3}\right.$ g.mL $\left.\mathrm{mL}^{-1}, \mathrm{EtOH}\right)=+66.1^{\circ}$.

1-Bz. With 3-Bz (205 mg, $1 \mathrm{mmol}), \mathrm{NaOH} 1 \mathrm{~N}$ (2.1 mL, $2.1 \mathrm{mmol}, 2 \mathrm{eq}), \mathrm{H}_{2} \mathrm{O}$ (2.1 mL, 0.12 mol, $111 \mathrm{eq})$ and $\mathrm{Br}_{2}(108(\mathrm{~L}, 2.1 \mathrm{mmol}, 2 \mathrm{eq})$. The reaction failed to provide tractable material.

1-iPr. With 3-iPr (200 mg, $1.4 \mathrm{mmol}), \mathrm{NaOH}$ (2.8 mL, $2.8 \mathrm{mmol}, 2 \mathrm{eq}), \mathrm{H}_{2} \mathrm{O}$ (2.8 mL, 0.16 mol, 111 eq) and $\mathrm{Br}_{2}\left(144 \mu \mathrm{L}, 2.8 \mathrm{mmol}, 2\right.$ equiv.). Yield $450 \mathrm{mg}(94 \%)$. M. p. 114-115 ${ }^{\circ} \mathrm{C}$. ${ }^{1} \mathrm{H}$ NMR $\left(\mathrm{ACN}-\mathrm{d}_{3}, 300 \mathrm{MHz}\right) \delta 0.96\left(\mathrm{~d},{ }^{3} J=6.9 \mathrm{~Hz}, 3 \mathrm{H}, \mathrm{CH}_{3}\right), 1.09\left(\mathrm{~d},{ }^{3} J=7.0 \mathrm{~Hz}, 3 \mathrm{H}\right.$, $\left.\mathrm{CH}_{3}\right), 2.26\left(\mathrm{qd},{ }^{3} J_{1}=7,0 \mathrm{~Hz},{ }^{3} J_{2}=3.2 \mathrm{~Hz}, 1 \mathrm{H}, \mathrm{CH}\left(\mathrm{CH}_{3}\right)_{2}\right), 4.13\left(\mathrm{dd},{ }^{3} J=3.2 \mathrm{~Hz}, 1 \mathrm{H}, \mathrm{CH}\right) .{ }^{13} \mathrm{C}$ NMR $\left(\mathrm{ACN}-\mathrm{d}_{3}, 75.5 \mathrm{MHz}\right) \delta 15.82\left(\mathrm{CH}\left(\underline{\mathrm{CH}}_{3}\right)_{2}\right), 16.45\left(\mathrm{CH}\left(\underline{\mathrm{CH}}_{3}\right)_{2}\right), 29.52\left(\underline{\mathrm{CH}}\left(\mathrm{CH}_{3}\right)_{2}\right), 72.68$ (CH), 154.89 (ㅁNBr), 169.36 (NBrCOONBr). Elem. Anal. Calcd. for $\mathrm{C}_{6} \mathrm{H}_{8} \mathrm{Br}_{2} \mathrm{~N}_{2} \mathrm{O}_{2}(\mathrm{M}=$ $\left.297.895 \mathrm{~g} \mathrm{~mol}^{-1}\right) \mathrm{C}, 24.03 ; \mathrm{H}, 2.69 ; \mathrm{N}, 9.34$. Found: C, 24.74; H, 3.19; N, $9.65 \%$. $[\alpha]_{\mathrm{D}}(\mathrm{c}=$ $\left.1.10^{-3} \mathrm{~g} \cdot \mathrm{mL}^{-1}, \mathrm{EtOH}\right)=-16.0^{\circ}$. 
1-iBu. With 3-iBu (205 mg, $0.7 \mathrm{mmol}), \mathrm{NaOH}$ (2.6 mL, $2.6 \mathrm{mmol}, 2$ equiv.), $\mathrm{H}_{2} \mathrm{O}$ (2.6 mL, 0.14 mol, 111 equiv.) and $\mathrm{Br}_{2}$ (131 ì , $2.6 \mathrm{mmol}, 2$ equiv.). The mixture is stirred at $10^{\circ} \mathrm{C}$ after $\mathrm{Br}_{2}$ addition for only $10 \mathrm{mn}$. Yield: $198 \mathrm{mg}(90 \%)$. M. p. 100-101 ${ }^{\circ} \mathrm{C} .{ }^{1} \mathrm{H}$ NMR (ACN$\left.\mathrm{d}_{3}, 300 \mathrm{MHz}\right) 0.92\left(\mathrm{~d},{ }^{3} J=6.6 \mathrm{~Hz}, 3 \mathrm{H}, \mathrm{CH}_{3}\right), 0.98\left(\mathrm{~d},{ }^{3} J=6.6 \mathrm{~Hz}, 3 \mathrm{H}, \mathrm{CH}_{3}\right), 1.72(\mathrm{~m}, 2 \mathrm{H}$, $\left.\mathrm{CH}_{2}\right), 4.24\left(\mathrm{t},{ }^{3} J=5.5 \mathrm{~Hz}, 1 \mathrm{H}, \mathrm{CH}\right) .{ }^{13} \mathrm{C} \mathrm{NMR}\left(\mathrm{ACN}_{-} \mathrm{d}_{3}, 75.5 \mathrm{MHz}\right) \delta(\mathrm{ppm}): 21.63$ $\left(\mathrm{CH}\left(\underline{\mathrm{CH}_{3}}\right)_{2}\right), 21.99\left(\mathrm{CH}\left(\underline{\mathrm{CH}}_{3}\right)_{2}\right), 23.94 \quad\left(\underline{\mathrm{CH}}\left(\mathrm{CH}_{3}\right)_{2}\right), 38.43\left(\underline{\mathrm{CH}}_{2}\right), 66.90(\mathrm{CH}), 154.77$ (ㅁNBr), $170.47(\mathrm{NBr} \underline{\mathrm{CONBr}}) .[\alpha]_{\mathrm{D}}\left(\mathrm{c}=9 \cdot 6 \cdot 10^{-4} \mathrm{~g} \cdot \mathrm{mL}^{-1}, \mathrm{EtOH}\right)=-8.3^{\circ}$.

Synthesis of the adducts.

$\mathrm{DBH} \bullet[\mathrm{Py}-\mathrm{CN}]$. DBH (15 mg, $\left.5.2510^{-5} \mathrm{~mol}\right)$ was dissolved in 1,2-dichloroethane (2 mL). 4Cyanopyridine (15 mg, $15.7510^{-5} \mathrm{~mol}$ ) was added. The solution was filtered to remove nondissolved particles and poured in a Durham tube. Crystals were obtained by vapor diffusion method. Hexane was used as precipitant. The sample was left to $2^{\circ} \mathrm{C}$ during 8 days in the dark. White crystals were obtained. M. p. $148^{\circ} \mathrm{C} .{ }^{1} \mathrm{H}$ NMR $\left(300 \mathrm{MHz}, \mathrm{DMSO}-d_{6}\right) \delta 8.81$ (dd, $J=1.6$ and $\left.4.5 \mathrm{~Hz}, 2 \mathrm{H}, \mathrm{H}_{\mathrm{Ar}}\right), 7.67\left(\mathrm{~d}, J=1.6\right.$ and $\left.4.5 \mathrm{~Hz}, 2 \mathrm{H}, \mathrm{H}_{\mathrm{Ar}}\right), 1.39$ (s, 6H, $\left.\mathrm{CH}_{3}\right)$. Elem. Anal. Calcd for $\mathrm{C}_{11} \mathrm{H}_{10} \mathrm{Br}_{2} \mathrm{~N}_{4} \mathrm{O}_{2}\left(\mathrm{M}=387.917 \mathrm{~g} \mathrm{~mol}^{-1}\right)$ : C, 33.87; H, 2.58; N, $14.36 \%$. Found: C, 33.99; H, 2.44; N, $14.37 \%$.

$\mathrm{DBH} \bullet\left[\mathrm{Py}-\mathrm{CF}_{3}\right] . \mathrm{DBH}\left(15 \mathrm{mg}, 5.2510^{-5} \mathrm{~mol}\right.$ ) and 4-trifluoromethylpyridine (30 $\mu \mathrm{L}, 15.75$ $\left.10^{-5} \mathrm{~mol}\right)$ were dissolved in dichloromethane $(4 \mathrm{~mL})$. The solution was filtered to remove non-dissolved particles. The solution was left to evaporate during 8 days in the dark at room temperature. White crystals were obtained. M. p. $196^{\circ} \mathrm{C} .{ }^{1} \mathrm{H}$ NMR $\left(300 \mathrm{MHz}, \mathrm{DMSO}-d_{6}\right) \delta$ $8.96-8.79(\mathrm{~m}, 2 \mathrm{H}), 7.79(\mathrm{~m}, 2 \mathrm{H}), 1.31-0.97(\mathrm{~m}, 6 \mathrm{H})$. Elem. Anal. Calcd. for $\mathrm{C}_{11} \mathrm{H}_{10} \mathrm{Br}_{2} \mathrm{~F}_{3} \mathrm{~N}_{3} \mathrm{O}_{2}\left(\mathrm{M}=433.02 \mathrm{~g} \mathrm{~mol}^{-1}\right)$ : C, 30.51; H, 2.33; N, $9.70 \%$. Found: $\mathrm{C}, 30.50 ; \mathrm{H}$, $2.64 ; \mathrm{N}, 11.18 \%$.

$\mathrm{DBH} \cdot\left[\mathrm{Py}-\mathrm{CO}_{2} \mathrm{Me}\right]$. DBH (15 mg, $\left.5.2510^{-5} \mathrm{~mol}\right)$ was dissolved in chlorobenzene (2 mL). 4Methylisonicotinate $\left(21 \mu \mathrm{L}, 15.7510^{-5} \mathrm{~mol}\right)$ was added. The solution was filtered to remove non-dissolved particles and poured in a Durham tube. Crystals were made by vapor diffusion method. Hexane was used as precipitant. The sample was left at $2^{\circ} \mathrm{C}$ during 8 days in the dark. White crystals were obtained. M.p. $134^{\circ} \mathrm{C} .{ }^{1} \mathrm{H}$ NMR $\left(300 \mathrm{MHz}\right.$, acetonitrile- $\left.d_{3}\right) \delta 8.79$ $\left(\mathrm{dd}, J=4.4 \mathrm{~Hz}\right.$ and $\left.1.6 \mathrm{~Hz}, 2 \mathrm{H}, \mathrm{H}_{\mathrm{Ar}}\right), 7.86\left(\mathrm{dd}, J=4.4 \mathrm{~Hz}\right.$ and $\left.1.6 \mathrm{~Hz}, 2 \mathrm{H}, \mathrm{H}_{\mathrm{Ar}}\right), 3.94(\mathrm{~s}, 3 \mathrm{H}$, 
$\left.\mathrm{COOCH}_{3}\right), 1.39$ (s, 6H, 2xCH 3$)$. Elem. Anal. Calcd. for $\mathrm{C}_{12} \mathrm{H}_{13} \mathrm{Br}_{2} \mathrm{~N}_{3} \mathrm{O}_{4}\left(\mathrm{M}=423.061 \mathrm{~g} \mathrm{~mol}^{-}\right.$ $\left.{ }^{1}\right)$ : C, 35.77; H, 2.67; N, $9.63 \%$. Found: C, 34.23; H, 3.04; N, $9.94 \%$.

$(\mathrm{DBH})_{2}\left(\right.$ pyrazine). DBH $\left(15 \mathrm{mg}, 5.2510^{-5} \mathrm{~mol}\right)$ was dissolved in $\mathrm{CH}_{2} \mathrm{Cl}_{2}(2 \mathrm{~mL})$. Pyrazine (21 $\mu \mathrm{L}, 15.7510^{-5} \mathrm{~mol}$ ) was added. The solution was filtered to remove non-dissolved particles and poured in a Durham tube. Crystals were made by vapor diffusion method. Hexane was used as precipitant. The sample was left at $2{ }^{\circ} \mathrm{C}$ during 8 days in the dark. White crystals were obtained. M. p. $159^{\circ} \mathrm{C} .{ }^{1} \mathrm{H}$ NMR $\left(300 \mathrm{MHz}, \mathrm{DMSO}-d_{6}\right) \delta 8.66\left(\mathrm{~s}, 4 \mathrm{H}, \mathrm{H}_{\mathrm{Ar}}\right), 1.50$ (s, 12H, $\left.\mathrm{CH}_{3}\right)$. Elem. Anal. Calcd. for $\mathrm{C}_{14} \mathrm{H}_{16} \mathrm{Br}_{4} \mathrm{~N}_{6} \mathrm{O}_{4}\left(\mathrm{M}=651.936 \mathrm{~g} \mathrm{~mol}^{-1}\right): \mathrm{C}, 25.79 ; \mathrm{H}$, 2.47 ; N, $12.89 \%$. Found: C, 25.97; H, 2.44; N, $12.71 \%$.

$[1-\mathrm{iBu}] \cdot\left[\mathrm{Py}-\mathrm{CO}_{2} \mathrm{Me}\right] .1$-iBu $\left(15 \mathrm{mg}, 4.7810^{-5} \mathrm{~mol}\right)$ was dissolved in 1,2-dichloroethane (2 $\mathrm{mL})$. 4-Methylisonicotinate $\left(17 \mu \mathrm{L}, 9.5610^{-5} \mathrm{~mol}\right)$ was added. The solution was filtered to remove non-dissolved particles and poured in Durham tube. Crystals were made by vapor diffusion method. Hexane was used as precipitant. The sample was left to $2^{\circ} \mathrm{C}$ during 8 days in the dark. White crystals were obtained. M.p. 97-98 ${ }^{\circ}$ C. Elem. Anal. Calcd. for $\mathrm{C}_{14} \mathrm{H}_{17} \mathrm{Br}_{2} \mathrm{~N}_{3} \mathrm{O}_{4}\left(\mathrm{M}=451.115 \mathrm{~g} \mathrm{~mol}^{-1}\right)$ : C, 37.28; H, 3.80; N, $9.31 \%$. Found: $\mathrm{C}, 37.80 ; \mathrm{H}$, $3.86 ; \mathrm{N}, 9.44 \%$.

Crystallography. X-ray crystal structure collections were performed on an APEXII BrukerAXS diffractometer equipped with a CCD camera and a graphite-monochromated Mo-K $\alpha$ radiation source $(\lambda=0.71073 \AA$ ). Details of the structural analyses are summarized in Table 2. Absorption corrections were performed with SADABS. Structures were solved by direct methods using the SIR97 program, ${ }^{41}$ and then refined with full-matrix least-squares methods based on $\mathrm{F}^{2}$ (SHELXL-97) ${ }^{42}$ with the aid of the WINGX program. ${ }^{43}$ All non-hydrogen atoms were refined with anisotropic atomic displacement parameters. $\mathrm{H}$ atoms were finally included in their calculated positions. Crystallographic data were deposited as CCDC 1509929: $\mathrm{DBH} \bullet[\mathrm{Py}-\mathrm{CN}] \bullet\left(\mathrm{C}_{2} \mathrm{H}_{4} \mathrm{Cl}_{2}\right)_{0.5} ; \mathrm{CCDC}$ 1509930: (DBH) $)_{2} \bullet$ Pyrazine; CCDC 1509931: DBH•[Py$\left.\mathrm{CO}_{2} \mathrm{Me}\right]$; CCDC 1509932: [1-iBu]•[Py-CO $\left.2 \mathrm{Me}\right]$ and CCDC 1509933: $\mathrm{DBH} \bullet\left[\mathrm{Py}-\mathrm{CF}_{3}\right]$. 
Table 2 Crystallographic data

\begin{tabular}{|c|c|c|c|c|c|}
\hline & $\begin{array}{l}(\mathrm{DBH})_{2} \bullet \\
\text { Pyrazine }\end{array}$ & $\begin{array}{l}\mathrm{DBH} \bullet[\mathrm{Py}-\mathrm{CN}] \bullet \\
\left(\mathrm{C}_{2} \mathrm{H}_{4} \mathrm{Cl}_{2}\right)_{0.5}\end{array}$ & $\begin{array}{l}\mathrm{DBH} \bullet \\
{\left[\mathrm{Py}-\mathrm{CF}_{3}\right]}\end{array}$ & $\begin{array}{l}\mathrm{DBH} \bullet \\
{\left[\mathrm{Py}-\mathrm{CO}_{2} \mathrm{Me}\right]}\end{array}$ & $\begin{array}{l}{[1-\mathrm{iBu}] \bullet} \\
{\left[\mathrm{Py}-\mathrm{CO}_{2} \mathrm{Me}\right]}\end{array}$ \\
\hline Formula & $\mathrm{C}_{7} \mathrm{H}_{8} \mathrm{Br}_{2} \mathrm{~N}_{3} \mathrm{O}_{2}$ & $\mathrm{C}_{12} \mathrm{H}_{12} \mathrm{Br}_{2} \mathrm{ClN}_{4} \mathrm{O}_{2}$ & $\mathrm{C}_{11} \mathrm{H}_{10} \mathrm{Br}_{2} \mathrm{~F}_{3} \mathrm{~N}_{3} \mathrm{O}_{2}$ & $\mathrm{C}_{12} \mathrm{H}_{13} \mathrm{Br}_{2} \mathrm{~N}_{3} \mathrm{O}_{4}$ & $\mathrm{C}_{14} \mathrm{H}_{17} \mathrm{Br}_{2} \mathrm{~N}_{3} \mathrm{O}_{4}$ \\
\hline $\mathrm{FW}\left(\mathrm{g} \cdot \mathrm{mol}^{-1}\right)$ & 325.98 & 439.53 & 433.04 & 423.07 & 451.12 \\
\hline System & triclinic & monoclinic & monoclinic & triclinic & orthorhombic \\
\hline Space group & $\mathrm{P}-1$ & $\mathrm{C} 2 / \mathrm{m}$ & $\mathrm{P} 2{ }_{1} / \mathrm{c}$ & $\mathrm{P}-1$ & $\mathrm{P} 2{ }_{1} 2_{1} 2_{1}$ \\
\hline$a(\AA)$ & $7.7140(4)$ & $8.6301(5)$ & $9.4108(4)$ & $6.1692(8)$ & $6.5779(5)$ \\
\hline$b(\AA)$ & $8.0925(4)$ & $7.7579(7)$ & $7.9826(3)$ & $7.9700(10)$ & $7.9462(5)$ \\
\hline$c(\AA)$ & $9.1626(4)$ & $23.769(2)$ & $19.9558(10)$ & $15.743(2)$ & $32.486(2)$ \\
\hline á (deg) & $64.045(3)$ & 90.00 & 90.00 & $88.236(5)$ & 90.00 \\
\hline â (deg) & $81.550(4)$ & $98.599(4)$ & $97.418(2)$ & $81.458(5)$ & 90.00 \\
\hline ã (deg) & $85.532(4)$ & 90.00 & 90.00 & $85.411(5)$ & 90.00 \\
\hline$V\left(\AA^{3}\right)$ & $508.65(4)$ & $1573.5(2)$ & $1486.59(11)$ & $762.90(17)$ & $1698.0(2)$ \\
\hline$T(\mathrm{~K})$ & $150(2)$ & $150(2)$ & $150(2)$ & $150(2)$ & $150(2)$ \\
\hline$Z$ & 2 & 2 & 4 & 2 & 4 \\
\hline$D_{\text {calc }}\left(\mathrm{g} \cdot \mathrm{cm}^{-1}\right)$ & 2.128 & 1.855 & 1.935 & 1.842 & 1.765 \\
\hline$\mu\left(\mathrm{mm}^{-1}\right)$ & 7.946 & 5.330 & 5.492 & 5.331 & 4.796 \\
\hline Total refls & 3773 & 4030 & 8226 & 5692 & 13213 \\
\hline Abs corr & multi-scan & multi-scan & multi-scan & multi-scan & multi-scan \\
\hline$T_{\min }, T_{\max }$ & $0.106,0.356$ & $0.209,0.619$ & $0.429,0.547$ & $0.116,0.726$ & $0.587,0.746$ \\
\hline$\theta_{\max }\left({ }^{\circ}\right)$ & 25.03 & 27.41 & 27.52 & 27.58 & 27.473 \\
\hline Uniq refls & 1799 & 1929 & 3382 & 3446 & 3881 \\
\hline$R_{\text {int }}$ & 0.0308 & 0.0417 & 0.0378 & 0.0368 & 0.0503 \\
\hline Uniq refls & 1539 & 1609 & 2684 & 2684 & 3351 \\
\hline$[\mathrm{I}>2 \sigma(\mathrm{I})]$ & & & & & \\
\hline$R_{1}$ & 0.0282 & 0.0536 & 0.0339 & 0.0559 & 0.0313 \\
\hline$w R_{2}$ (all data) & 0.0775 & 0.1428 & 0.1177 & 0.1774 & 0.0574 \\
\hline Flack param. & - & - & - & - & $0.011(8)$ \\
\hline GOF & 1.108 & 1.058 & 0.819 & 1.035 & 1.048 \\
\hline $\begin{array}{l}\text { Res. dens. } \\
\left(\mathrm{e} \AA^{-3}\right)\end{array}$ & $0.482,-0.746$ & $1.603,-1.841$ & $0.650,-0.801$ & $1.422,-1.173$ & $0.405,-0.420$ \\
\hline
\end{tabular}




\section{Notes and references}

1 (a) L. Pauling, R. B. Corey and H. R. Branson, Proc. Natl. Acad. Sci. U. S. A., 1951, 37, 205; (b) J. D. Watson and F. H. C. Crick, Nature, 1953, 171, 737; (c) A. Rich and F. H. C. Crick, Nature, 1955, 176, 915; (d) K. P. Meurer and F. P. Vögtle, Top. Curr. Chem., 1985, 127, 1 .

2 (a) I. Sato, R. Yamashima, K. Kadowaki, J. Yamamoto, T. Shibata and K. Soai, Angew. Chem., 2001, 113, 1130; (b) J. L. Zhou, Y. X. Wang, Y. Wang, Y. L. Song, H. G. Zheng, Y. Z. Li, L. P. Yang and X. Q. Xin, CrystEngComm, 2003, 5, 62; (c) M. Reggelin, S. Doerr, M. Klussmann, M. Schultz and M. Holbach, Proc. Natl. Acad. Sci. U. S. A., 2004, 101, 5461

3 (a) S. Krishnaswamy, R. G. Gonnade, M. S. Shashidhar and M. M. Bhadbhade, CrystEngComm, 2010, 12, 4184, (b) T. Sasaki, I. Hisaki, S. Tsuzuki,, N. Tohnaia and M. Miyata, CrystEngComm, 2012, 14, 5749.

4 (a) V. K. Praveen, S. S. Babu, C. Vijayakumar, R. Varghese and A. Ajayaghosh, Bull. Chem. Soc. Jpn., 2008, 81, 1196; (b) J.-C. Xiao, J.-L. Xu, S. Cui, H.-B. Liu, S. Wang and Y.-L. Li, Org. Lett., 2008, 10, 645; (c) F. Dumitru, Y.-M. Legrand, A. V. Lee and M. Barboiu, Chem. Commun., 2009, 2667.

5 G. Cavallo, P. Metrangolo, R. Milani, T. Pilati, A. Priimagi, G. Resnati and G. Terraneo, Chem. Rev., 2016, 116, 2478-2601.

${ }^{6}$ For the IUPAC definition of halogen bond, see: G. R. Desiraju, P. Shing Ho, L. Kloo, A. C. Legon, R. Marquardt, P. Metrangolo, P. Politzer, G. Resnati, and K. Rissanen, Pure Appl. Chem., 2013, 85, 1711-1713.

7 (a) Halogen Bonding: Fundamentals and Applications; P. Metrangolo, G. Resnati, Eds.; Structure and Bonding 126 ; Springer-Verlag: Berlin, 2008; (b) G. Cavallo, P. Metrangolo, T. Pilati, G. Resnati, M. Sansotera and G. Terraneo, Chem. Soc. Rev., 2010, 39, 3772; (c) P. Politzer, J. S. Murray and T. Clark, Phys. Chem. Chem. Phys., 2010, 12, 7748.

8 G. Cavallo, P. Metrangolo, T. Pilati, G. Resnati, and G. Terraneo, Cryst. Growth Des., 2014, 14, 2697.

9 (a) P. Metrangolo, T. Pilati, G. Terraneo, S. Biella and G. Resnati, CrystEngComm, 2009, 11, 1187; (b) G. Cavallo, P. Metrangolo, T. Pilati, G. Resnati, M. Sansoterra, G. Terraneo, Chem. Soc. Rev., 2010, 39, 3772; (c) F. Meyer and P. Dubois, CrystEngComm, 2013, 15, 3058; (d) A. Mukherjee, S. Tothadi and G. R. Desiraju, Acc. Chem. Res., 2014, 47, 2514. 
${ }^{10}$ A. Farina, S. V. Meille, M. T. Messina, P. Metrangolo, G. Resnati and G. Vecchio, Angew. Chem. Int. Ed., 1999, 38, 2433.

11 T. Sasaki, Y. Ida, I. Hisaki, S. Tsuzuki, N. Tohnai, G. Coquerel, H. Sato and M. Miyata, Cryst. Growth. Des., 2016, 16, 1626-1635

12 K. S. Eccles, R. E. Orrison, C. A. Daly, G. E. O'Mahony, A. R. Maguire and S. E. Lawrence, CrystEngComm, 2013, 15, 7571-7575.

13 (a) M. Brezgunova, K. S. Shin, P. Auban-Senzier, O. Jeannin, M. Fourmigué, Chem. Commun. 2010, 3226-3228 (b) K.-S. Shin, M. Brezgunova, O. Jeannin, T. Roisnel, F. Camerel, P. Auban-Senzier, M. Fourmigué, Cryst. Growth Design, 2011, 11, 5337-5345

14 J. Lieffrig, R. Le Pennec, O. Jeannin, P. Auban-Senzier and M. Fourmigué, CrystEngComm, 2013, 15, 4408.

15 (a) C. Präsang, A. C. Whitwood and D. W. Bruce, Chem. Commun., 2008, 2137-2139; (b)

D. W. Bruce, P. Metrangolo, F. Meyer, T. Pilati, C. Prasang, G. Resnati, G. Terraneo, S.

G. Wainwright and A. C. Whitwood, Chem. Eur. J., 2010, 16, 9511-9524.

${ }^{16}$ S. Castro-Fernandez, I. R. Lahoz, A. L. Llamas-Saiz, J. L. Alonso-Gomez, M. M. Cid and A. Navarro-Vazquez, Org. Lett., 2014, 16, 1136-1139.

17 (a) S. Muniappan, S. Lipstman, I. Goldberg, Chem. Commun. 2008, 1777-1779; (b) H. M. Titi, G. Nandi, B. K. Tripuramallu and I. Goldberg, Cryst. Growth Des., 2015, 15, 30633075; (c) G. Nandi, H. Titi, and I. Goldberg, Cryst. Growth Des., 2014, 14, 3557-3566.

18 J. Y. Lim, I. Marques, L. Ferreira, V. Felix, P. D. Beer, Chem. Commun., 2016, 52, $5527-$ 5530.

${ }^{19}$ J. Lieffrig, A. G. Niassy, O. Jeannin and M. Fourmigué, CrystEngComm 2015, 17, 50-57

${ }^{20}$ R. W. Troff, T. Mäkelä, F. Topi, A. Valkonen, K. Raatikainen and K. Rissanen, Eur. J. Org. Chem. 2013, 1617-1637.

${ }^{21}$ R. Puttreddy, O. Jurcek, S. Bhowmik, T. Makela and K. Rissanen, Chem. Commun., 2016, 52, 2338-2341.

${ }^{22}$ K. Raatikainen and K. Rissanen, Chem. Sci., 2012, 3, 1235-1239.

${ }^{23}$ D. Dolenc and M. Modec, New J. Chem., 2009, 33, 2344-2349.

${ }^{24}$ O. Makhotkina, J. Lieffrig, O. Jeannin, M. Fourmigué, E. Aubert and E. Espinosa, Cryst. Growth Des., 2015, 15, 3464-3473.

25 (a) C. Chassaing, A. Haudrechy, Y. Langlois Tetrahedron Lett., 1997, 38, 4415-4416; (b)

G. Hernandez-Torres, B. Tan, C. F. Barbas, Org. Lett. 2012, 14, 1858-1861. 
${ }^{26}$ (a) A. Khazaei, M.A. Zolfigol, A. Rostami, Synthesis, 2004, 18, 2959-2961; (b) M. Tabata, K. Moriyama, H. Togo, Eur. J. Org. Chem., 2014, 16, 3402-3410.

27 I. Nicolas, F. Barrière, O. Jeannin, and M. Fourmigué, Cryst. Growth Des., 2016, 16, 2963-2971.

28 (a) M. Meusel, S. Gutschow, Org. Prep. Proced. Int., 2004, 36, 391-443; (b) M. Dhanawat, A. G. Banejee, S. K. Shrivastava, Med. Chem. Res., 2011, 21, 2807-2822; (c) H. Kutt, C. L. Harden, Handb. Exp. Pharmacol., 1999, 138, 229-265; (d) Z. Iqbal, S. Ali, J. Iqbal, Q. Abbas, I. Z. Qureshi, S. Hameed, Bioorg. Med. Chem. Lett., 2013, 23, 488-491.

${ }^{29}$ (a) R. Yousefi, D. C. Whitehead, J. M. Mueller, R. J. Staples and B. Borhan, Org. Lett., 2011, 13, 608-611; (b) D. C. Whitehead, R. J. Staples, B. Borhan, Tetrahedron Lett., 2009, 50, 656-658.

${ }^{30}$ R. A. Corral, O. O. Orazi and J. D. Bonafede, Anal. Assoc. Quim. Argent., 1957, 45, 151159.

31 (a) J. Marton, J. Enisz, S. Hosztafi, T. Timar, J. Agric. Food Chem., 1993, 41, 148-152. (b) H. D. Dakin, H. W. Dudley, J. Biol. Chem., 1914, 17, 29-36.

32 (a) L. Konnert, B. Reneaud, R. Marcia de Figueiredo, J-M. Campagne, F. Lamaty, J. Martinez, E. Colacino, J. Org. Chem., 2014, 79, 10132-10142; (b) G. D. Cuny, J. Yuan, P. Jagtap, A. Degterev, US 20050119260A1, 2005; (c) M. Moriya, H. Ohta, Shuji Yamamoto, K. Abe, Y. Araki, X.-Min Sun, D. Wakasugi, US 20130331571 A1, 2013.

${ }^{33}$ M. Garst, L. Dolby, S. Esfandiari, WO2007025271A1, 2007.

${ }^{34}$ I. Markish , O. Arrad, Ind. Eng. Chem. Res., 1995, 34, 2125-2127.

${ }^{35}$ C. Laurence, J. Graton, M. Berthelot, M. J. El Ghomari, Chem. Eur. J., 2011, 17, 1043110444

${ }^{36}$ K. Rissanen, M. Haukka, Top. Curr. Chem., 2015, 359, 77-90.

37 (a) A.-C. C. Carlsson, M. Uhrbom, A. Karim, U. Brath, J. Gräfenstein, M. Erdélyi, CrystEngComm, 2013, 15, 3087-3092; (b) S. B. Hakkert, M. Erdelyi, J. Phys. Org. Chem., 2015, 28, 226-233; (c) M. Bedin, A. Karim, M. Reitti, M.; A.-C. C. Carlsson, F. Topić, M. Cetina, F. Pan, V. Havel, F. Al-Ameri, V. Sindelar, K. Rissanen, J. Gräfenstein, M. Erdélyi, Chem. Sci., 2015, 6, 3746-3756 and references therein

38 (a) A.-C. C. Carlsson, J. Gräfenstein, A. Budnjo, J. L. Laurila, J. Bergquist, A. Karim, R. Kleinmaier, U. Brath, M. Erdélyi, J. Am. Chem. Soc., 2012, 134, 5706-5715; (b) A.-C. C. Carlsson, J. Gräfenstein, J. L. Laurila, J. Bergquist, M. Erdélyi, Chem. Commun., 2012, 48, $1458-1460$. 
${ }^{39}$ K. H. Dudley, D. L. Bius, J. Heterocycl. Chem., 1973, 10, 173-180.

${ }^{40}$ T. Suzuki, K. Igarashi, K. Hase, K. Tuzimura, Agric. Biol. Chem., 1973, 37, 411-416.

${ }^{41}$ A. Altomare, M. C. Burla, M. Camalli, G. Cascarano, C. Giacovazzo, A. Guagliardi, A. G. G. Moliterni, G. Polidori, R. Spagna, J. Appl. Cryst., 1999, 32, 115-119.

${ }^{42}$ G. M. Sheldrick, Acta Crystallogr., 2008, A64, 112-122.

${ }^{43}$ L. J. Farrugia, J. Appl. Cryst., 2012, 45, 849-854. 